\title{
Simulating Urban Land Expansion in the Context of Land Use Planning in the Abuja City-Region, Nigeria
}

\author{
Evidence Chinedu Enoguanbhor • Florian Gollnow • Blake Byron Walker • \\ Jonas Ostergaard Nielsen · Tobia Lakes
}

Accepted: 8 October 2020/Published online: 22 October 2020

(C) The Author(s) 2020

\begin{abstract}
In the Global South, including the SubSaharan African city-regions, the possible future urban expansion patterns may pose a challenge towards improving environmental sustainability. Land use planning strategies and instruments for regulating urban expansion are faced with challenges, including insufficient data availability to offer insights into the possible future urban expansion. This study integrated empirical data derived from Geographic Information Systems, Remote Sensing, and surveys of experts to
\end{abstract}

E. C. Enoguanbhor $(\varangle) \cdot$ J. O. Nielsen · T. Lakes Applied Geoinformation Science Laboratory, Institute of Geography, Humboldt University of Berlin, Unter den Linden 6, 10099 Berlin, Germany

e-mail: evidence.chinedu.enoguanbhor@geo.hu-berlin.de

E. C. Enoguanbhor · J. O. Nielsen · T. Lakes

Integrative Research Institute on Transformations of Human-Environmental Systems, Humboldt University of Berlin, Unter den Linden 6, 10099 Berlin, Germany

E. C. Enoguanbhor

Department of Geography, FCT College of Education,

Zuba-Abuja, P.M.B. 61 Garki-Abuja, Abuja, Nigeria

F. Gollnow

Department of Earth and Environment, Boston University, 685 Commonwealth Avenue, Boston,

MA 02215, USA

B. B. Walker

Institute for Geography, Friedrich-Alexander Universität Erlangen-Nürnberg, Wetterkreuz 15, 91058 Erlangen, Germany offer insights into the possible future urban expansion under spatial planning scenarios to support land use planning and environmental sustainability of cityregions. We analyzed the spatial determinants of urban expansion, calibrated the land cover model using the Multi-Layer Perceptron Neural Network and Markov, and developed three scenarios to simulate land cover from 2017 to 2030 and to 2050. The scenarios include Business As Usual that extrapolates past trends; Regional Land Use Plan that restricts urban expansion to the land designated for urban development, and; Adjusted Urban Land that incorporates the leapfrogged settlements into the land designated for urban development. Additionally, we quantified the potential degradation of environmentally sensitive areas by future urban expansion under the three scenarios. Results indicated a high, little, and no potential degradation of environmentally sensitive areas by the future urban expansion under the Business As Usual, Adjusted Urban Land, and Regional Land Use Plan scenarios respectively. The methods and the baseline information provided, especially from the Adjusted Urban Land scenario showed the possibility of balancing the need for urban expansion and the protection of environmentally sensitive areas. This would be useful to improve the environmental sustainability of the Sub-Saharan African city-regions and across the Global South, where insufficient data availability challenges land use planning. 
Keywords Environmental sustainability .

Scenarios · Urban expansion · Urban planning ·

Regional planning $\cdot$ Sub-Saharan Africa

\section{Introduction}

The possible future urban expansion may pose significant negative impacts on environmentally sensitive areas (Mohamed and Worku 2020; Gao et al. 2020), considering the past/current unregulated urban expansion patterns in the Global South (Aldana-Domínguez et al. 2019; Agyemang et al. 2019; Agyemang and Silva 2019; Li et al. 2018; Barrera and Henríquez 2017). This may pose a challenge towards improving environmental sustainability in Sub-Saharan Africa where this expansion is often happening at rapid rates (Enoguanbhor et al. 2019; Agyemang et al. 2019; Agyemang and Silva 2019; Kukkonen et al. 2018). Also, the challenge may hinder achieving the United Nations' sustainable development goal of "making cities and human settlements inclusive, safe, resilient, and sustainable" (United Nations 2019, p. 44).

To regulate urban expansion patterns, including the haphazard and leapfrogging, where vacant lands are skipped to develop farther lands from the city center (Agyemang and Silva 2019; Chen et al. 2017), land use planning is often suggested (Wang et al. 2014). Land use planning can be understood as a deliberate process of defining land to different uses to balance social, economic, and environmental objectives (Phillips and João 2017). In Abuja, land use planning has not been able to regulate the leapfrogged/haphazard urban expansion patterns for the past 3 decades, despite the existence of urban and regional plans (Enoguanbhor et al. 2019). At the same time, Abuja could be a role model because it is a new settlement and the future certainly means change and expansion that can be regulated using land use planning strategies at urban and regional scales. Also, it is the only city developed from scratch using land use planning strategies (Adama, 2020). However, land use planning as a strategic action is being challenged with insufficient data availability in the Global South (Schug et al. 2018; Potts 2012). Therefore, a need to integrate empirical data from different sources to predict the possible future urban expansion patterns exists. This can be achieved by integrating the Geographic
Information Systems (GIS-which is an organized assemblage of interrelated components that interacts with one another to generate facts from raw data related to the location and distribution of objects in space) with Remote Sensing (RS) and surveys.

In Abuja, Nigeria, previous research (e.g., Enoguanbhor et al. 2019; Mashi and Shuaibu 2018; Usman 2013; Ejaro and Abubakar 2013; Ade and Afolabi 2013; Fanan et al. 2011; Idoko and Bisong 2010; Ujoh et al. 2010) have successfully analyzed past urban expansion but without developing scenarios of possible future urban expansion and with little or no implications for future environmentally sensitive areas designated by land use plans. In one of the few studies about future urban development in Abuja, Nigeria, Mahmoud et al. (2016) show that the possible future urban dynamics in Abuja, Nigeria may grow significantly to the detriment of vegetation cover, but the authors did not develop spatial planning scenarios for the prediction. Chima (2012) simulates Abuja urban expansion from 2006 to 2020 and shows the rapid loss of non-urban land to urban development, but the author did not consider developing alternative scenarios to protect environmentally sensitive areas from future urban expansion. In other parts of Nigeria, Tope-Ajayi et al. (2016); Agbor et al. (2012) predict that urban/built-up areas may continue to expand into non-urban development areas in the Eleyele wetland area, and Ibadan metropolis respectively, however without considering spatial planning scenarios to analyze the protection of environmentally sensitive areas. In other parts of Sub-Saharan Africa, Mohamed and Worku (2020); Agyemang and Silva (2019); and Kukkonen et al. (2018) simulate the future urban expansion of Addis Ababa, Ethiopia, Accra, Ghana, and Zanzibar, Tanzania respectively. However, the authors did not incorporate the leapfrogged settlements and land use designated for urban development by regional plans to restrict the future urban expansion. This would make it difficult or impossible for land use planning strategies to regulate the leapfrogging urban expansion patterns from land use designated for non-urban development. Similar urban land predictions were made outside Sub-Saharan Africa. For example, Nor et al. (2017) predict the future urban expansion of three cities, Kuala Lumpur, Malaysia; Jakarta, Indonesia, and Metro Manila, Philippines. The study shows that urban expansion may lead to a drastic reduction of green spaces in the cities but the 
study did not consider spatial planning to analyze the protection of environmentally sensitive areas. Gao et al. (2020) simulate future urban expansion of Wenzhou, China, and report that in all scenarios, urban expansion caused significant losses in ecologically valuable lands. These existing findings/studies raise an important question: can the environmentally sensitive areas designated by land use plans be protected from the possible future urban dynamics, considering the need and high rate of urban expansion patterns in the city-regions?

Therefore, the goal of this study is to investigate the possibility of balancing the need for urban expansion and protection of environmentally sensitive areas designated by land use plans. The study aims to integrate empirical data derived from GIS, RS, and surveys of experts to offer insights into the possible future urban expansion under spatial planning scenarios to support land use planning and environmental sustainability of city-regions. The objectives of the current study are to (1) identify the spatial determinants of urban expansion to select the driver variables for future urban expansion; (2) use expert interviews to guide the development of scenarios of likely urban expansion for different spatial planning alternatives to simulate land cover from 2017 to 2030 and to 2050; (3) contrast experts' opinions on the potential future demands for urban land expansion under different scenario implementation, and; (4) quantify the potential degradation of environmentally sensitive areas by the possible future urban expansion. By contrasting different scenarios of future urban expansion to quantify the associated potential degradation of environmentally sensitive areas, this paper provides new insights for sustainable land use planning and urban development. This study, therefore, contributes to land use planning as a strategic instrument to regulate the leapfrogging/haphazard urban expansion and improve environmental sustainability, particularly in the Global South.

\section{Literature Review}

In the last few decades, urban expansion has drawn attention within the research and professional communities to manage the expanding cities with the consideration of the cultural, social, economic, and environmental developments for current and future generations (Enoguanbhor et al. 2019; Agyemang and
Silva 2019; Tope-Ajayi et al. 2016). Expanding cities are culturally, socially, economically, and environmentally networked with surrounding, as well as distant urban and rural settlements that define cityregions (Davoudi 2009; Seto et al. 2012). In this context, the extent and boundaries of a city-region are difficult to define (Seto et al. 2012) but generally, a city-region comprises one or more cities that are closely interlinked, together with other surrounding settlements with significant spatial interactions (Harding et al. 2006).

Previous urban studies (e.g., Mohamed and Worku 2020; Gao et al. 2020; Agyemang and Silva 2019; Agyemang, et al. 2019; Enoguanbhor et al. 2019; Nor et al. 2017; Ade and Afolabi 2013) analyzed the past, current, and/or future spatial patterns, and the environmental and/or land use planning implications in city-regions. Urban expansion in city-regions, especially in Sub-Saharan Africa, takes the shape of haphazard and urban leapfrogged patterns (Agyemang and Silva 2019; Agyemang et al. 2019). For example, in the Abuja city-region, Nigeria (particularly in some peri-urban/satellite settlements, e.g., Lugbe town), the haphazard urban expansion emerged through the process of urban leapfrogging (Enoguanbhor et al. 2019). Also, leapfrogged urban expansion patterns in the Accra city-region, Ghana was reported by Agyemang and Silva (2019). Such urban expansion patterns are associated with spatial determinants, which are factors contributing to the explanation of the location of land or environmental dynamics (Meyfroidt 2016).

The environmental dynamics of urban expansion can be reflected through the removal of vegetation (e.g., in environmentally sensitive areas) for urban development (Enoguanbhor et al. 2019; Tope-Ajayi et al. 2016; Ade and Afolabi 2013). The removal of vegetation poses a significant threat to biodiversity, causing species habitat fragmentation and extinction (Tope-Ajayi et al. 2016; Ade and Afolabi 2013). While analyzing the environmental dynamics of future urban expansion under different scenario alternatives, Gao et al. (2020) claim that the future urban dynamics of Wenzhou, China may cause less encroachment into environmentally sensitive areas, without considering additional determinants of urban expansion. In other studies, (e.g., Mohamed and Worku, 2020), a similar scenario features a high degradation of environmentally sensitive areas by the possible future urban expansion when compared to alternative scenarios in 
the Addis Ababa city-region, Ethiopia. The environmental dynamics of urban expansion patterns in SubSaharan African city-regions have not been addressed effectively using land use planning strategies (Enoguanbhor et al. 2019; Mahmoud et al. 2016; Ade and Afolabi 2013).

\section{Materials and Methods}

Study Area

The current study focuses on the Abuja city-region of Nigeria (Fig. 1), considering the leapfrogged/haphazard urban expansion patterns, especially in peri-urban/ satellite settlements in the past 3 decades (Enoguanbhor et al. 2019). The region was created as the Federal Capital Territory (FCT) of Nigeria in 1976 to develop a new capital city that is free from social and environmental problems associated with the formal capital, Lagos (FMITI 2015; Sufiyan et al. 2015; Abubakar 2014; Ade and Afolabi 2013; Ejaro and Abubakar 2013). Land use planning strategies and instruments were explicitly developed and adopted to foster sustainable development before relocating the government seat from Lagos to Abuja in 1991 (Adama 2020; Idoko and Bisong 2010). Among the purpose of the land use planning strategies is the preservation of the natural environment and coordination of land use (COHRE and SERAC 2008; Jelili et al. 2008). The original land use plans were designed based on 25 years of development plans that made provisions for constant review to accommodate developments beyond the 25 years (Abubakar 2014). However, our informal conversations with the experts indicate that a comprehensive review has not been carried out on the regional plan but the plan was reproduced in the year 2000. Despite adopting land use planning strategies at urban and regional scales to develop the new FCT, the leapfrogging/haphazard urban expansion patterns contribute to the challenges towards improving environmental sustainability in the city-region. The satellite settlements feature haphazard developments and the Abuja city features a well-planned landscape that serves as the Central Business District (CBD) to other settlements in the city-region (Enoguanbhor et al. 2019). As a city-region, some satellite settlements have developed their CBDs, making the entire region features multiple CBDs.

The FCT Abuja is one of the fastest-growing cityregions in the Global South with a population growth rate of about $5.3 \%$ (Mashi and Shuaibu 2018). The population of FCT Abuja was 1,400,000 in 2006 (Adama 2020) and was projected to 2,292,413 in 2015 (Mashi and Shuaibu 2018). Regarding the urban and regional economy, the FCT Abuja is one of the regions
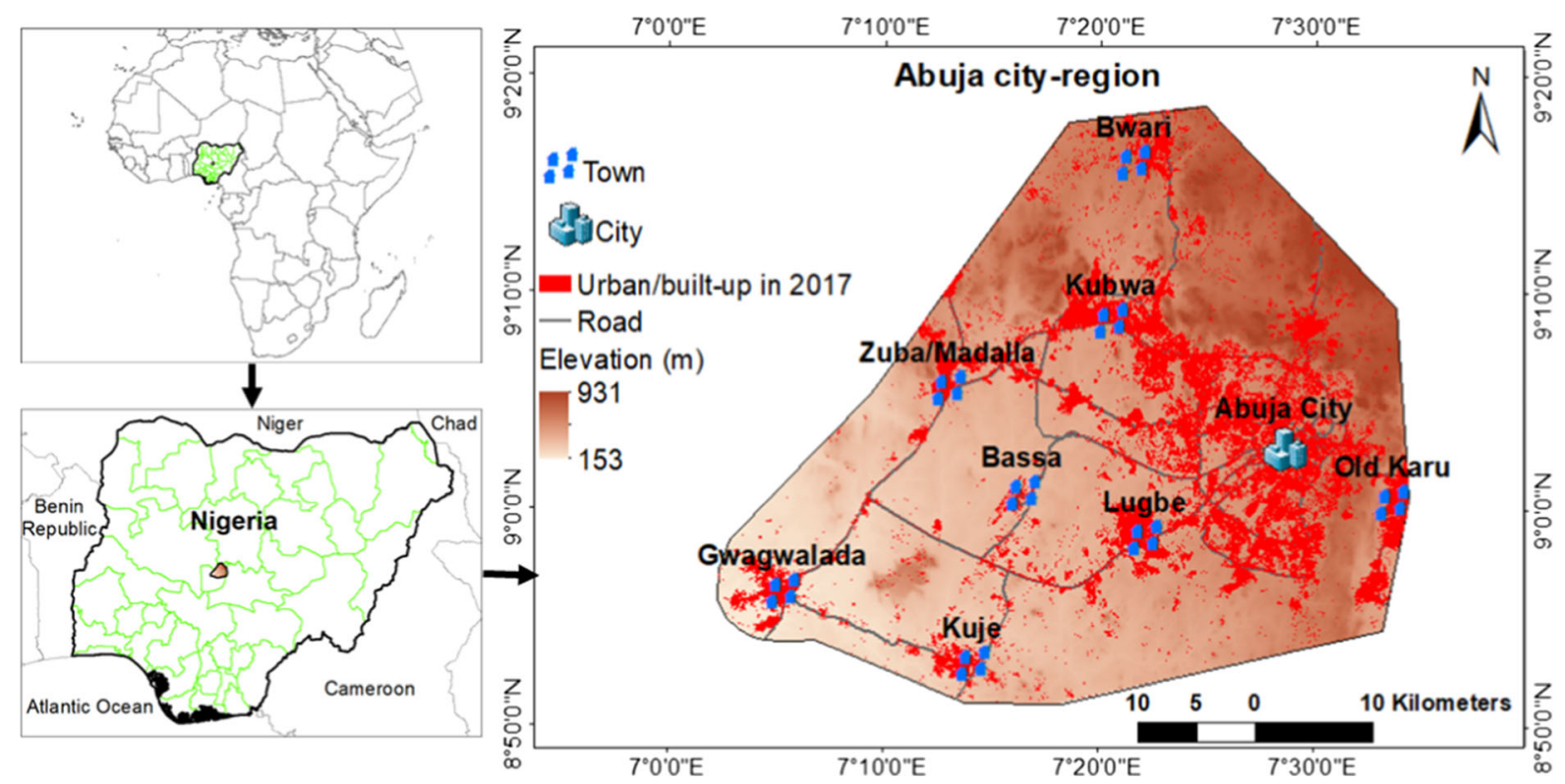

Fig. 1 Map showing the location of the Abuja city-region in Nigeria 
contributing the highest Gross Domestic Product (GDP) (about $\$ 5,612$ ) to the Nigerian economy in 2015 (Bloch et al. 2015).

\section{Data Collection}

We collected land cover maps of the Abuja city-region produced by Enoguanbhor et al. (2019). The land cover maps were produced from LANDSAT 7 and 8 satellite images captured in 2002, and 2017 respectively. Also, we collected a Digital Elevation Model (DEM) from the Shuttle Radar Topography Mission (SRTM) (Jarvis et al. 2008), a satellite image of the Nigeriasat-2 from the National Space and Research Development Agency (NASRDA) (NASRDA 2012), and used Google Earth imagery (2018). Additionally, we collected a satellite image that was captured in 2019 by LANDSAT 8 from the United States Geological Survey (USGS) Earth Explorer service (USGS 2019). Furthermore, we collected a regional land use plan from the Abuja Geographic Information Systems (AGIS) (AGIS 2007). Table 1 summarizes the description of GIS and remotely sensed data.

We designed a mixed questionnaire that includes open-ended and matrix questions to survey experts in urban and regional planning. The matrix questionnaire is a format that offers an efficient presentation of a set of closed-ended questions with the same response categories (Babbie 2013; Secor 2010). We administered questionnaires to experts using snowball nonprobability sampling (Babbie 2013, 2010; Blaxter et al. 2001). We distributed and retrieved a total of 25 questionnaires at the government departments/agencies, including the Department of Urban and Regional Planning, Abuja (10), the Department of Urban and
Regional Development of the Federal Ministry of Housing, Abuja (7). Others include the Department of Development Control, Abuja (4), and the Nigerian Institute of Town Planners, Abuja (4). The work experience of the respondents ranges from 0-10 years (20\%), 11-20 years (52\%), 21-30 years (12\%), and 31 years and above (16\%). The respondent's highest academic level completed constitutes Bachelor or equivalent (16\%), Masters or equivalent $(68 \%)$, and $\mathrm{PhD}$ or equivalent $(16 \%)$. The survey was conducted from 4 July to 5 August 2019 by the first author. The language used was the English Language.

\section{Data Analysis}

\section{Analyses of Spatial Determinants and Experts' Opinions}

We defined and evaluated multiple bivariate and multivariate logistic regression models using $\mathrm{R}$ programming version 3.5.3. We used several variables, describing the physical location, distance to roads, higher institutions and other infrastructure, and environmentally protected areas, as explanatory variables that potentially determine the location of current and future urban expansion (Table 2). While generating parameters for the variables, we used ArcGIS 10.6 version to perform the Euclidean distance modeling by measuring from sampled locations to the variables. To reduce or eliminate bias in the model, we checked the multi-collinearity problem by calculating the Variance Inflation Factor (VIF) of the independent variables to make sure the variables have independent effects on the dependent variable (Visser and Jones III 2010). We defined iteratively exclude variables with a VIF larger

Table 1 GIS and remotely sensed data description

\begin{tabular}{lllll}
\hline & GIS and RS data & Year & Spatial resolution & Sources \\
\hline 1 & Land cover map & 2002 & $30 \mathrm{~m}$ & Enoguanbhor et al. (2019) \\
2 & Land cover map & 2017 & $30 \mathrm{~m}$ & Enoguanbhor et al. (2019) \\
3 & Landsat 8 satellite image & 2019 & $30 \mathrm{~m}$ & USGS (2019) \\
4 & Nigeriasat-2 satellite image & 2012 & $2.5 \mathrm{~m}$ & NASRDA (2012) \\
5 & Google Earth & 2017 & - & Google Earth (2018) \\
6 & Digital Elevation Model & 2008 & $90 \mathrm{~m}$ & SRTM (Jarvis et al. 2008) \\
7 & FCT Abuja regional land use plan & Reproduced in 2000 & - & AGIS (AGIS 2007) \\
\hline
\end{tabular}


Table 2 Independent variables for spatial determinants of urban expansion, the expected associations, and description

\begin{tabular}{|c|c|c|c|c|}
\hline & $\begin{array}{l}\text { Independent } \\
\text { variables }\end{array}$ & $\begin{array}{l}\text { Expected } \\
\text { association }\end{array}$ & Reasons & Citations \\
\hline 1 & Elevation & Negative & Urban expansion mostly occurs on low elevation levels & $\begin{array}{l}\text { Li et al. (2018), Mahmoud et al. } \\
\text { (2016), Zhang and Su (2016), } \\
\text { Akintunde et al. (2016) }\end{array}$ \\
\hline 2 & $\begin{array}{l}\text { Degrees of } \\
\text { slope }\end{array}$ & Negative & Urban expansion mostly occurs on flat topographies & $\begin{array}{l}\text { Li et al. (2018), Zhang and Su } \\
\text { (2016) }\end{array}$ \\
\hline 3 & $\begin{array}{l}\text { Distance to } \\
\text { water } \\
\text { bodies }\end{array}$ & Positive & $\begin{array}{l}\text { At the regional scale, accessibility to water bodies attracts } \\
\text { urban development }\end{array}$ & - \\
\hline 4 & $\begin{array}{l}\text { Distance to } \\
\text { roads }\end{array}$ & Positive & Urban land tends to develop towards road networks & $\begin{array}{l}\text { Simwanda and Murayama } \\
\text { (2018), Chang et al. (2016) }\end{array}$ \\
\hline 5 & $\begin{array}{l}\text { Distance to } \\
\text { CBDs }\end{array}$ & Positive & $\begin{array}{l}\text { At the regional scale, the distribution of CBDs of various } \\
\text { settlements contributes to urban expansion patterns due to } \\
\text { spatial interactions between the settlements }\end{array}$ & - \\
\hline 6 & $\begin{array}{l}\text { Distance to } \\
\text { higher } \\
\text { institutions }\end{array}$ & Positive & $\begin{array}{l}\text { From the urban morphological viewpoint, the locations of the } \\
\text { institutions of higher learning attract urban development due } \\
\text { to the influx of people and businesses }\end{array}$ & Larkham (2000) \\
\hline 7 & $\begin{array}{l}\text { Distance to } \\
\text { shopping } \\
\text { centers }\end{array}$ & Positive & $\begin{array}{l}\text { Accessibility to markets attracts urban development, including } \\
\text { residential and industrial projects }\end{array}$ & Linard et al. (2013) \\
\hline 8 & $\begin{array}{l}\text { Distance to } \\
\text { planned } \\
\text { areas }\end{array}$ & Positive & $\begin{array}{l}\text { At the regional scale, land designated for urban planning } \\
\text { attracts urban development and the spatial patterns of urban } \\
\text { plans contribute to urban expansion patterns }\end{array}$ & $\begin{array}{l}\text { Chen et al. (2016), Nnaemeka- } \\
\text { Okeke (2016), Shi et al. (2009) }\end{array}$ \\
\hline 9 & $\begin{array}{l}\text { Distance to } \\
\text { protected } \\
\text { areas }\end{array}$ & Negative & $\begin{array}{l}\text { With the effective implementation of strategic actions on } \\
\text { protected areas, such areas are not allowed for urban } \\
\text { development projects }\end{array}$ & - \\
\hline
\end{tabular}

than 5. We calculated the odds ratios to determine the level of association between the independent and dependent variables.

We applied the descriptive statistics to analyze the questionnaire data set characteristics by calculating the sampled frequencies (Visser and Jones III 2010) and identifying variables (spatial determinants of urban expansion). Additionally, we analyzed the open questions qualitatively using the process of coding and synthesizing (Bryman 2016; Maxwell 2013; Secor 2010) to identify expert's opinions on land designated for urban development by the regional plan. According to Secor (2010), coding is a systematic process of flagging themes, words, phrases, and interpretations of the surveyed transcripts. We sorted and synthesized the coded variables and ranked them as follows: $\mathrm{x}=$ "Very low" (1-2); $\mathrm{xx}=$ "Low" (3-4); xxx = " High" (5-6) and; $x x x x=$ "Very high" (7 and above), where $1-2,3-4$, etc. are the number of times a variable is identified by various respondents.

\section{Model calibration and validation}

We calibrated the land cover types using the MultiLayer Perceptron (MLP) neural network and Markov models. According to Singha et al. (2012), the MLP neural network uses the non-linear function to compute the weights of multiple input layers to produce a single output layer and can be expressed as:

$\mathrm{Y}=\mathrm{f}\left(\sum_{i=1}^{n} \mathrm{WiXi}+\mathrm{B}\right)$

where $\mathrm{Y}$ is the output layer, $\mathrm{Wi}$ is the weight for input layer $\mathrm{i}, \mathrm{Xi}$ is the input for layers $\mathrm{i}$. B is the bias, which is a constant that helps the model fits best, and $\mathrm{f}$ is the transfer function, sigmoid, which allows the classification of non-linear patterns in the data. Markov model, according to Koomen and Stillwell (2007) states that the initial state of a cell, the surrounding cells, and a transition matrix with its transition 
probabilities determine the probability of the cell to change its function. Markov model can be expressed as:

$\mathrm{L}_{\mathrm{t} 2}=\mathrm{f}\left(\mathrm{L}_{\mathrm{t} 1}, \mathrm{~N}_{\mathrm{t} 1}\right)$

where $\mathrm{L}_{\mathrm{t} 2}$ is the state of the cell that changes its function, $\mathrm{L}_{\mathrm{t} 1}$ is the state of the initial cell, $\mathrm{N}_{\mathrm{t} 1}$ is the state of the surrounding cell of $\mathrm{L}_{\mathrm{t} 1}$, and $\mathrm{f}$ is the function of the transition matrix with its transition probability.

We performed the analysis through various steps in ArcGIS 10.6 and TerrSet 18.3 versions. First, we reclassified the land cover maps for 2002 and 2017 into urban/built-up and non-urban/built-up. Second, we performed change analysis to assess the transitions between 2002 and 2017 land cover types to define the transition sub-model to be evaluated. Third, we chose spatial determinants of urban expansion as the driver variables to be included in the sub-model, which was based on the expected association with urban expansion. We tested the chosen driver variables in TerrSet and based on their probability values and coefficients, we finally selected topographic elevation and distance to protected areas as static variables. Additionally, we selected distances to roads and urban/built-up for 2002 and 2017 as dynamic variables. Fourth, we ran the transition sub-model successfully with accuracy at $79 \%$, skill measure at 0.6 , training data at 0.5 , and testing data at 0.5 to produce the transition potential of the sub-model using the MLP neural network. Finally, we used the transition potential to analyze change prediction to 2019 land cover using the Markov model with the transition probability/area matrix in Table 3. At this level, we used the dynamic road development of change allocation modeling. We defined the dynamic road development parameters, including mode of rout generation as highest transition potential routes; road growth parameters as length $(40 \mathrm{~km})$ and spacing $(7.1 \mathrm{~km})$, and; skip factor as 1 . The skip factor is defined as 1 to make sure the dynamic variables are updated at every prediction date.
To validate the model, we produced the 2019 land cover map (Fig. 2b) using the supervised classification (Campbell and Wynne 2011) and the maximum likelihood algorithm (Lu et al. 2011; Tso and Mather 2009) in ArcGIS. We categorized the land cover classes into urban/built-up and non-urban/built-up and performed accuracy assessments of the classified land cover by sampling referenced points using a simple random sampling approach, in which every location has an equal chance to be included in the sample (Olofsson et al. 2014). We used a total of 511 points for validation on the composite satellite image for 2019 and calculated the user (errors of commission) and producer (errors of omission) accuracies at $86.2 \%$ and $89.8 \%$ respectively for urban/built-up, as well as overall accuracy (94.3\%) and Kappa coefficients (0.94). We used the actual 2019 land cover map to validate the predicted 2019 land cover map (Fig. 2a) and produced the 2019 validated map (Fig. 2c). The model validated at $1 \%$ Hits (the model predicted change and it changed), 7.8\% Misses (the model predicted persistence and it changed), $1.9 \%$ False alarms (the model predicted change and it persisted), and $90.3 \%$ overall accuracy $(100-$ (Misses + False alarms)).

\section{Developing Scenarios for Land Cover Simulation}

We developed three scenarios, Business As Usual (BAU), Regional Land Use Plan (RLUP), and Adjusted Urban Land (AUL) to simulate land cover from 2017 to 2030 and to 2050. The BAU scenario assumes the future urban spatial patterns based on extrapolating the past trends of land cover change from Enoguanbhor et al. (2019). To develop the spatial planning scenarios, we developed storylines from the surveys of land use planning experts. The experts gave contradicting opinions that the land designated for urban development by the current regional plan may or may not be sufficient for current and future developments. To avert future uncertainty, we developed the

Table 3 The transition probability/area matrix from 2002 and 2017 to 2019

\begin{tabular}{llll}
\hline Land cover types & Urban/built-up & Non-urban/built-up & Total \\
\hline Urban/built-up & $0.9276\left(357.18 \mathrm{~km}^{2}\right)$ & $0.0724\left(27.88 \mathrm{~km}^{2}\right)$ & $1\left(385.06 \mathrm{~km}^{2}\right)$ \\
Non-Urban/built-up & $0.0368\left(59.16 \mathrm{~km}^{2}\right)$ & $0.9632\left(1548.43 \mathrm{~km}^{2}\right)$ & $1\left(1607.59 \mathrm{~km}^{2}\right)$ \\
\hline
\end{tabular}



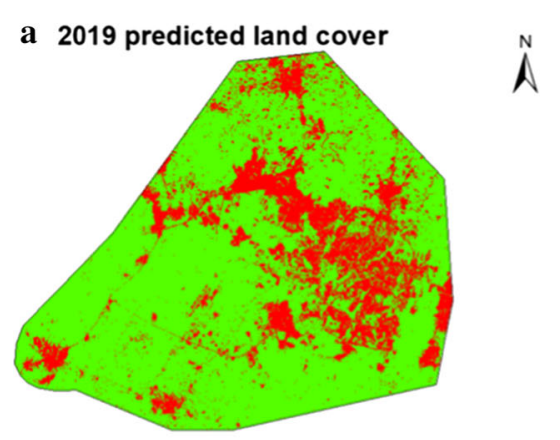

\section{c 2019 validated land cover}
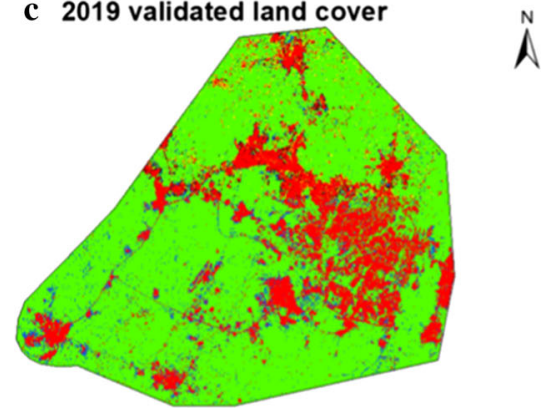

Fig. 2 Predicted, actual, and validated land cover maps for 2019

RLUP scenario under the current regional plan. In this context, the RLUP scenario assumes future urban spatial patterns to be restricted by land use designated for urban development under the current regional plan. Also, the experts opined that some leapfrogged settlements (e.g., Lugbe) should not be evacuated but integrated into the master plan and urban renewal and strict protection of the remaining forests should be adhered to. However, a high number of experts also disagreed. Based on this assumption, we developed the AUL scenario as a spatial planning alternative that integrates existing leapfrogged settlements on land designated for non-urban development, while considering the protection of the environmentally sensitive areas defined by the regional plan, including the protected ecological areas and forest reserve. The AUL scenario assumes future urban spatial patterns to be restricted by land use designated for urban development under the spatial planning alternative. The AUL can be seen as a spatial planning scenario to support the actualization of certain visions e.g., improving environmental sustainability, creating a functional urban environment. The essence of developing the AUL scenario is to analyze the possibility of meeting the need for future urban expansion and protecting environmentally sensitive areas of city-
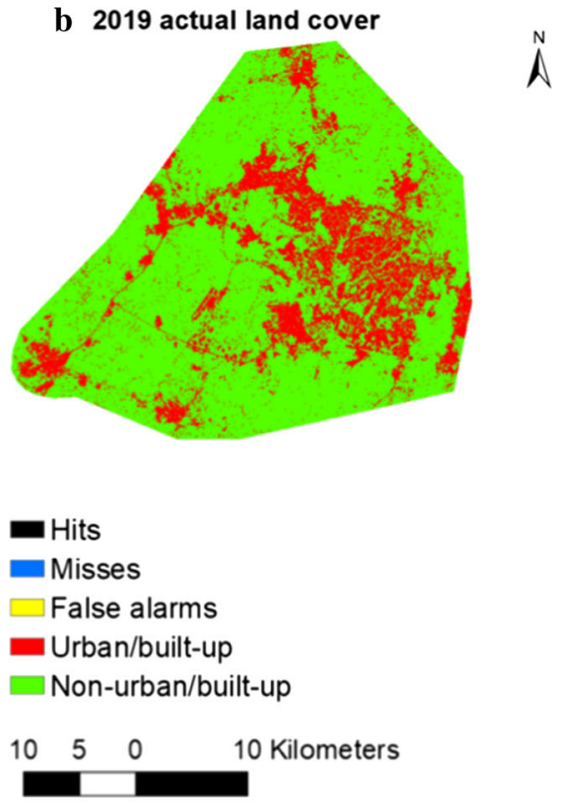

regions. Table 4 summarizes the main assumptions of the scenarios. At this level of simulation, we used the dynamic road development of change allocation modeling for the BAU scenario and additional zoning (constraints and incentives) of change allocation modeling for the RLUP and AUL scenarios.

\section{Quantifying the Potential Degradation of Environmentally Sensitive Areas}

We used the cartographic overlays to quantify the possible future urban expansion in the environmentally sensitive areas designated by the regional plan under the BAU, RLUP, and AUL scenarios of the possible future urban expansion patterns using the formula expressed as:

$\mathrm{EIM}=\mathrm{TLC}-\mathrm{LCD}$

where EIM is the environmental impact magnitude of future urban expansion, TLC is the total predicted urban/built-up land cover of the city-region, and LCD is the predicted urban/built-up land cover in the environmentally sensitive area. We used the quantification under the BAU scenario to determine the degradation level of the environmentally sensitive areas by the future urban expansion if the past/current 
Table 4 Scenarios for possible future urban expansion and their main assumptions

\begin{tabular}{lll}
\hline \multicolumn{1}{c}{ Scenarios } & Main assumptions \\
\hline 1 & BAU & The possible future urban expansion patterns based on extrapolating the past trends of land cover change \\
2 & RLUP & $\begin{array}{c}\text { The possible future urban expansion patterns to be restricted by land use designated for urban development under the } \\
\text { current regional plan }\end{array}$ \\
3 & AUL & $\begin{array}{c}\text { The possible future urban expansion patterns to be restricted by land use designated for urban development under the } \\
\text { spatial planning alternative }\end{array}$ \\
\hline
\end{tabular}

implementation of the regional plan continues. While we used the RLUP scenario to determine the degradation level if the current regional plan is implemented effectively, the AUL scenario was used to determine the degradation level if the adjusted urban land as the alternative regional plan is implemented effectively. Figure 3 summarizes the data types and analyses, where boxes in red, black, and green indicate data, analyses, and results respectively.

\section{Results and Discussion}

This study demonstrates the first detailed example of integrating empirical data derived from GIS, RS, and surveys of experts to offer insights into the possible future urban expansion under spatial planning scenarios to support land use planning and environmental sustainability in the Abuja city-region, Nigeria.

\section{Findings}

The results in Tables 5 and 6 show the spatial determinants of urban expansion based on data derived from GIS/RS and survey of experts respectively. From GIS/RS data, the bivariate model showed the level of elevation and distance to protected areas as negatively associated with the urban/built-up land, with elevation having the highest odds ratio. This indicates that the lower the elevation and the farther away from a protected area, the higher the likelihood of urban development. Conversely, distances to water bodies, roads, CBDs, higher institutions, shopping centers, planned area, and slope are positively associated with the urban/built-up land, with roads having the highest odds ratio. This indicates that the closer a location is from these variables, the more likely it will be developed. The degrees of the slope were excluded from the multivariate model due to unexpected results from the bivariate model. The low standard errors for all the variables indicated good models' fit. The less than 5 VIF for all the independent variables showed that the variables have independent effects on the dependent variable. From survey-based data, most experts perceived the level of elevation and distance to protected areas as positively associated with urban expansion patterns and the degrees of the slope as negatively associated with urban expansion patterns. The findings from the survey data analysis support GIS/RS on distances to roads, CBDs, higher institutions, shopping centers, urban planned areas, and water bodies but contradict results on the level of elevation, distance to protected areas, and the degrees of slope (Tables 5 and 6). The findings that with an increase in slope, the likelihood for urban development increases is unexpected and contradict previous studies from Xu et al. (2018); Li et al. (2018); Zhang and $\mathrm{Su}$ (2016) who reported slope as negatively associated with urban expansion in their various study areas. The findings that the distance to roads is positively associated with urban expansion patterns, however, is in line with earlier studies from Salem et al. (2019); Kleemann et al. (2017); Tsutsumida et al. (2015); Linard et al. (2013); Doan and Oduro (2012).

The results (Fig. 4) show the spatial patterns of the possible future urban expansion. While the BAU and AUL scenarios simulated land cover types to 2050 (Fig. 4d and e), the RLUP scenario simulated until 2030 (Fig. 4c), indicating the insufficient space for future urban expansion under the RLUP scenario. Under the BAU scenario, the results show that the urban expansion patterns may occur in a leapfrogged/ haphazard manner, especially on land designated for non-urban/built-up, similar to those reported by Agyemang and Silva (2019) for Accra city-region, Ghana that leapfrogged large-scale development 


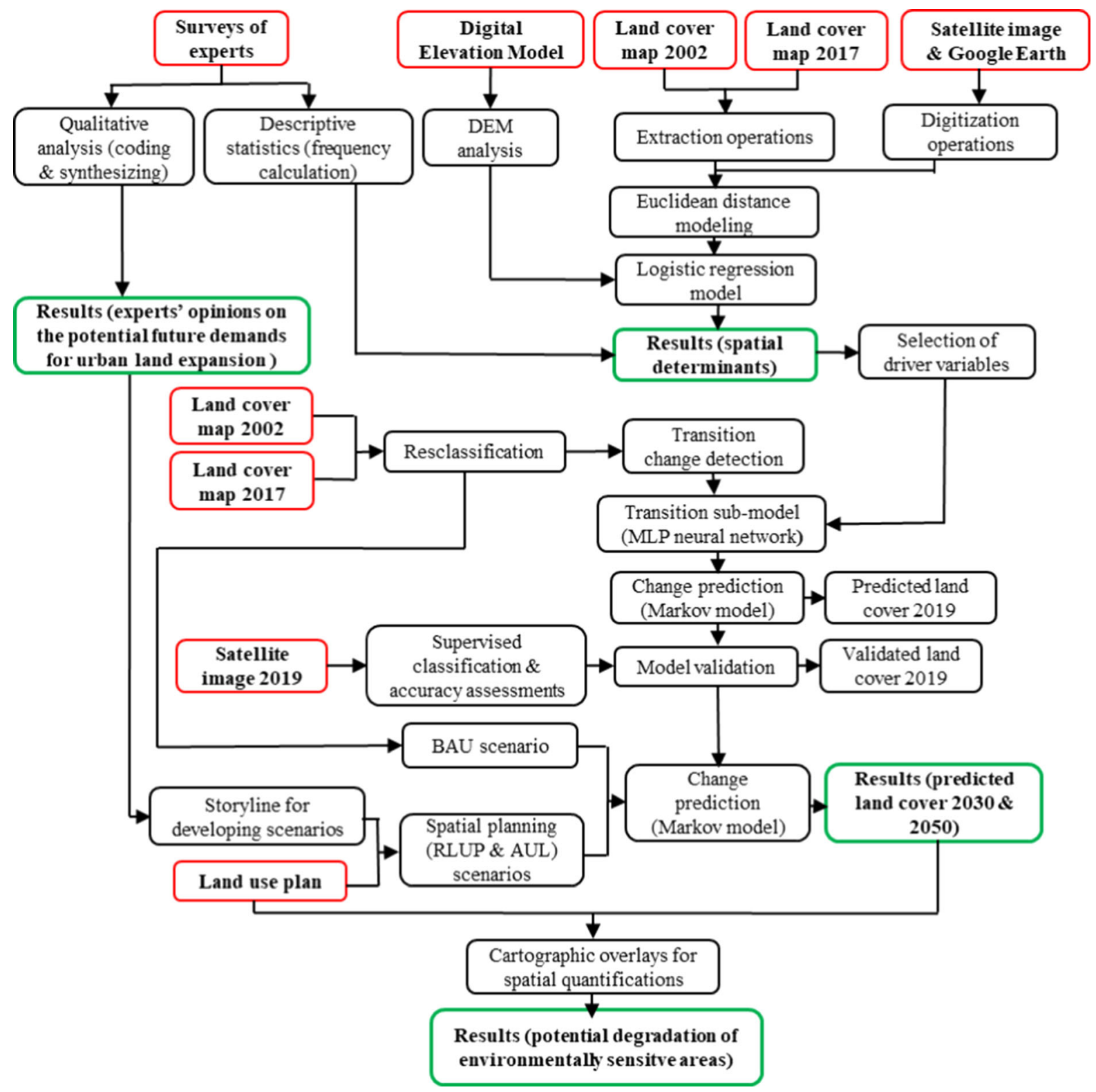

Fig. 3 Methods for simulating future urban land expansion to predict the potential degradation in environmentally sensitive areas

becoming new attraction centers. This result indicates gaps that may occur between the planned land designated for urban development and the possible future urban dynamics, similar to those predicted by Mahmoud et al. (2016) for future settlement expansion of Abuja who underscored that the expansion may occur without strict adherence to the master plan. Also, the results show that the Abuja urban dynamics may continue to grow outwardly and may feature similar patterns to the past and current urban expansion trends (Enoguanbhor et al. 2019; Mashi and Shuaibu 2018; Usman 2013; Ejaro and Abubakar 2013; Ade and Afolabi 2013; Fanan et al. 2011; Chima 2012; Idoko and Bisong 2010; Ujoh et al. 2010). The results are similar to the findings in other Nigerian cities reported by Tope-Ajayi et al. (2016); Agbor et al. (2012) who predicted that urban/built-up areas may continue to grow outwardly into non-urban development areas in the Eleyele wetland area and Ibadan metropolis. Similar findings have been 
Table 5 Spatial determinants of urban expansion until 2017 based on GIS analysis

\begin{tabular}{|c|c|c|c|c|c|c|c|c|c|}
\hline \multirow[t]{2}{*}{ Spatial determinants } & \multicolumn{4}{|c|}{ Bivariate } & \multicolumn{5}{|c|}{ Multivariate } \\
\hline & Coef. & Odds ratio & $P$-value & SE & Coef. & Odds ratio & $P$-value & SE & VIF \\
\hline 1 Elevation (100 m) & -0.00 & 1.00 & 0.00 & 0.00 & 0.00 & 1.00 & 0.00 & 0.00 & 2.71 \\
\hline 2 Slope (degree) & 0.06 & 1.06 & 0.00 & 0.00 & - & - & - & - & - \\
\hline 3 Dist. to water bodies $(\mathrm{km})$ & 0.06 & 1.06 & 0.00 & 0.00 & 0.05 & 1.05 & 0.00 & 0.00 & 2.81 \\
\hline 4 Dist. to roads (km) & 0.63 & 1.88 & 0.00 & 0.02 & 0.38 & 1.46 & 0.00 & 0.02 & 1.19 \\
\hline 5 Dist. to CBDs (km) & 0.20 & 1.22 & 0.00 & 0.01 & 0.10 & 1.11 & 0.00 & 0.01 & 3.72 \\
\hline 6 Dist. to higher institutions $(\mathrm{km})$ & 0.09 & 1.10 & 0.00 & 0.00 & -0.00 & 1.00 & 0.48 & 0.00 & 1.20 \\
\hline 7 Dist. to shopping centers $(\mathrm{km})$ & 0.36 & 1.43 & 0.00 & 0.01 & 0.14 & 1.15 & 0.00 & 0.02 & 3.44 \\
\hline 8 Dist. to planned area $(\mathrm{km})$ & 0.37 & 1.45 & 0.00 & 0.01 & 0.05 & 1.06 & 0.00 & 0.01 & 2.26 \\
\hline 9 Dist. to protected area $(\mathrm{km})$ & -0.15 & 0.86 & 0.00 & 0.00 & -0.12 & 0.88 & 0.00 & 0.00 & 2.28 \\
\hline
\end{tabular}

Null deviance: 19,704 on 19,999 degrees of freedom (multivariate). Residual deviance: 15,072 on 19,991 degrees of freedom (multivariate)

Table 6 Calculated frequencies of spatial determinants of urban expansion based on a survey of urban and regional planning experts

\begin{tabular}{|c|c|c|c|c|c|}
\hline \multicolumn{2}{|c|}{ Spatial determinants } & \multirow{2}{*}{$\frac{\text { Positive association (\%) }}{44}$} & \multirow{2}{*}{$\begin{array}{l}\text { Negative association }(\%) \\
40\end{array}$} & \multirow{2}{*}{$\begin{array}{l}\text { No/unknown association }(\%) \\
16\end{array}$} & \multirow{2}{*}{$\frac{\text { Total }(\%)}{100}$} \\
\hline 1 & Elevation & & & & \\
\hline 2 & Degrees of slope & 28 & 48 & 24 & 100 \\
\hline 3 & Distance to water bodies & 40 & 32 & 28 & 100 \\
\hline 4 & Distance to roads & 92 & 0 & 8 & 100 \\
\hline 5 & Distance to CBDs & 76 & 16 & 8 & 100 \\
\hline 6 & Distance to higher institutions & 68 & 8 & 24 & 100 \\
\hline 7 & Distance to shopping centers & 92 & 8 & 0 & 100 \\
\hline 8 & Distance to planned area & 92 & 8 & 0 & 100 \\
\hline 9 & Distance to protected areas & 44 & 32 & 24 & 100 \\
\hline
\end{tabular}

reported across Sub-Saharan Africa and other parts of the Global South. For example, Mohamed and Worku (2020); Gao et al. (2020); Agyemang and Silva (2019); Kukkonen et al. (2018); Xie et al. (2018); Nor et al. (2017); Inouye et al. (2015) predicted future urban expansion to the detriments of other land uses for nonurban development in their various study areas.

Table 7 shows the contradicting opinions from experts on current/future urban development and leapfrogging urban expansion in relation to the regional plan. While contrasting the experts' opinions on the potential future demands for urban land expansion under different scenario implementation, the results show that a very high number of experts opined that the land will be or not be sufficient for current and future developments. The RLUP scenario provides evidence in support of the group of experts' opinions that land designated for urban development may not be sufficient for future urban expansion under the current regional plan because the scenario could not simulate land cover to 2050 due to the limited space of land for future urban expansion. Also, a very high number of experts suggested that the settlements (e.g., Lugbe town) that emerged through leapfrogging should not be evacuated but integrated into the master plan and urban renewal and strict protection of the remaining forests should be adhered to. However, a high number of experts suggested that such settlements should be evacuated to implement the master plan. The AUL scenario, as a spatial planning 


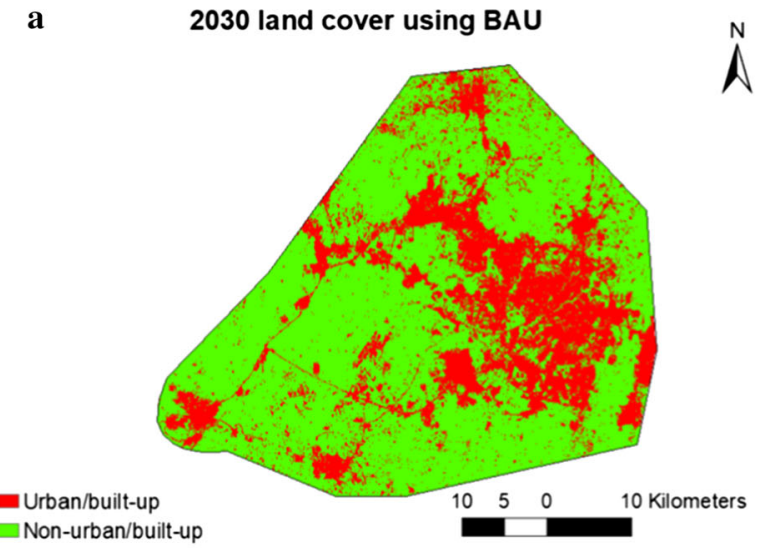

b

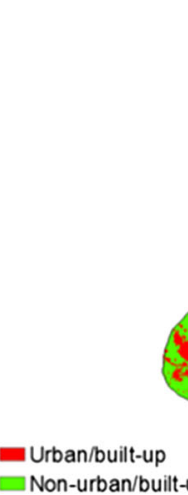

2030 land cover using RLUP

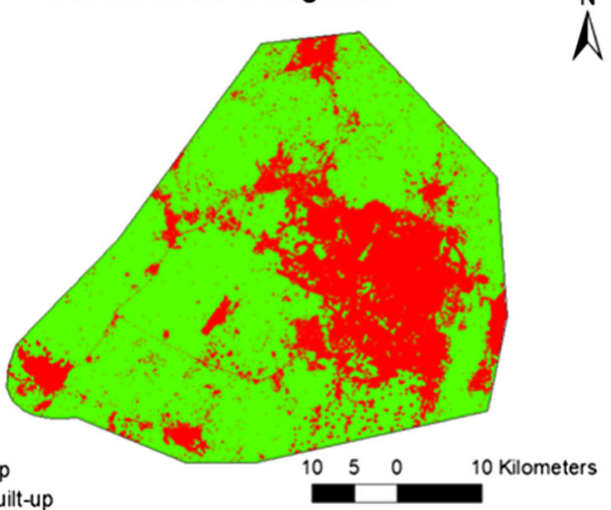

c

2030 land cover using AUL

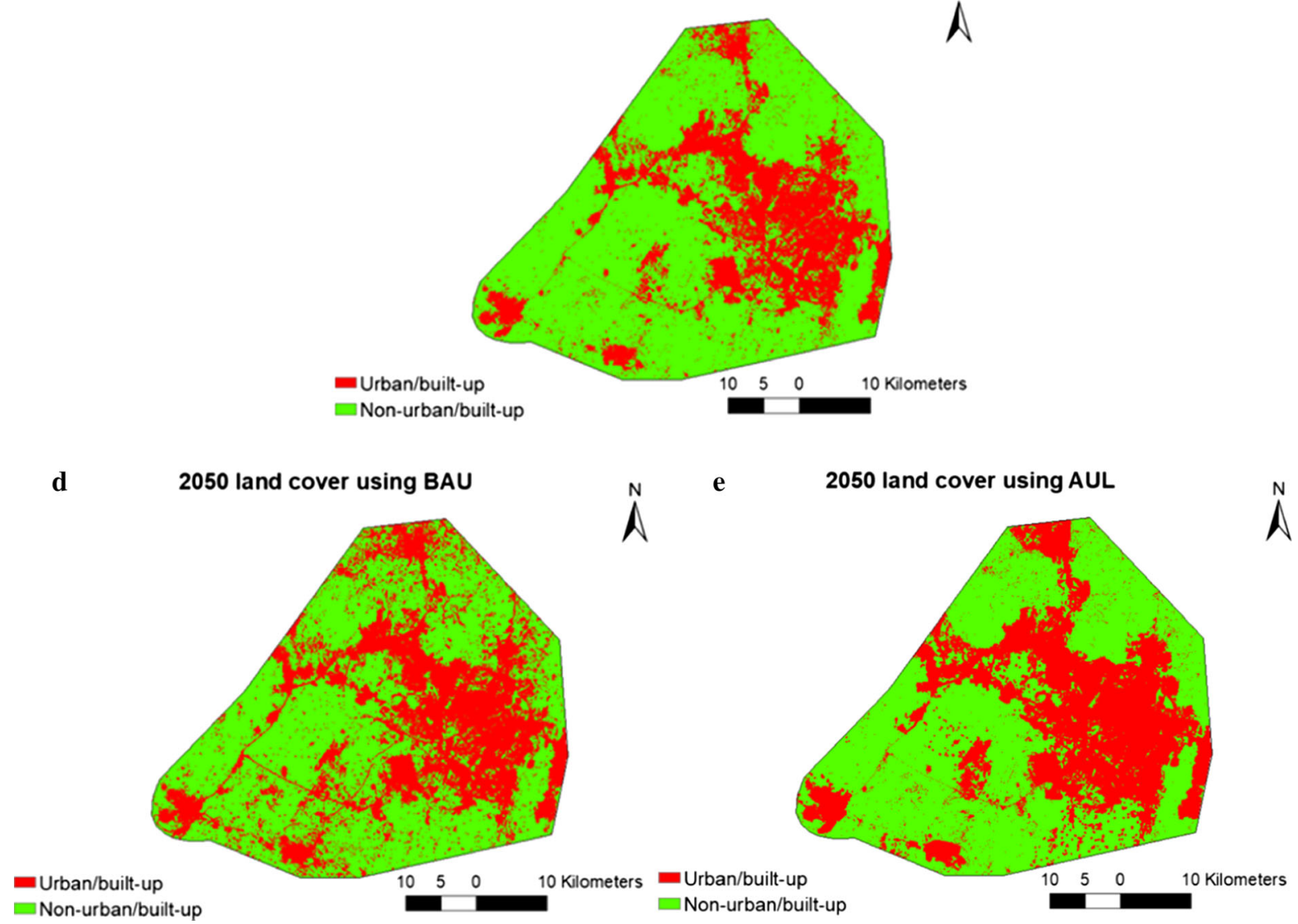

$\stackrel{N}{N}$

Fig. 4 Spatial patterns of the predicted land cover types using BAU, RLUP, and AUL scenarios

alternative provides evidence in support of the group of experts' opinions on settlements that emerged through leapfrogging should not be evacuated but integrated into the master plan. The contradicting opinions among the experts may be due to a lack of research on the possible future urban dynamics of the city-region using different spatial planning scenarios. The results (Fig. 5) show the spatial patterns of future urban/built-up land in relation to the environmentally sensitive areas designated by the regional 
Table 7 Experts' opinions on potential future demands for urban land expansion and leapfrog settlements

\begin{tabular}{|c|c|c|}
\hline Analyzed topics & Identified variables (opinions) & Ranking \\
\hline \multirow[t]{2}{*}{$\begin{array}{l}\text { Opinions on land designated for urban } \\
\text { development by the regional plan }\end{array}$} & $\begin{array}{l}\text { The land designated for urban development by the regional plan will be } \\
\text { sufficient for current and future developments }\end{array}$ & $\mathrm{xxxx}$ \\
\hline & $\begin{array}{l}\text { The land designated for urban development by the regional plan will not be } \\
\text { sufficient for current and future developments }\end{array}$ & $\mathrm{xxxx}$ \\
\hline \multirow[t]{2}{*}{$\begin{array}{l}\text { Suggested strategy for settlements that } \\
\text { emerged through leapfrogging }\end{array}$} & $\begin{array}{l}\text { The leapfrog settlements (e.g., Lugbe) should not be evacuated but } \\
\text { integrated into the master plan and urban renewal and strict protection of } \\
\text { the remaining forests should be adhered to }\end{array}$ & $\mathrm{xxxx}$ \\
\hline & $\begin{array}{l}\text { The leapfrog settlements (e.g., Lugbe) should be evacuated with total } \\
\text { resettlement to implement the original regional plan }\end{array}$ & $\mathrm{xxx}$ \\
\hline \multicolumn{3}{|c|}{ Ranking: $\mathrm{x}=$ "Very low" (1-2); $\mathrm{xx}=$ "Low" (3-4); $\mathrm{xxx}=$ "High" (5-6) and; $\mathrm{xxxx}=$ "Very high" $(7$ and above $)$} \\
\hline
\end{tabular}

plan. Under the BAU scenario, the results (Fig. $4 \mathrm{~b}$ and Table 8) show that the potential degradation of environmentally sensitive areas by the possible future urban expansion may increase from 2017 to 2050 and the degradation level may be higher than that of the spatial planning scenarios, indicating gaps that may occur between the regional plan and the possible future urban dynamics. These results coincide with those of Mohamed and Worku (2020), who claim that the degradation level of environmentally sensitive areas of future urban expansion under the BAU scenario may be higher than that of the Ecological Sensitive Scenario in the Addis Ababa city-region, Ethiopia. The results differ from those of Gao et al. (2020), who claim that under the BAU scenario, the future urban dynamics of Wenzhou, China may cause less encroachment into environmentally sensitive areas. The result shows that if the weaknesses in the implementation of the past/current land use plans are not addressed, the future implementation may not be able to protect environmentally sensitive areas effectively. Under the RLUP and AUL scenarios, the results show that there may be no and little degradation of environmentally sensitive areas respectively, indicating effective planning restrictions of urban expansion into such areas (Fig. 5c, d, and Table 8). The results provide support for Mohamed and Worku (2020) on the Ecological Sensitive scenario.

Implications of the Findings

An important implication of the findings is that without effective spatial planning restrictions, the possible future urban dynamics under the BAU scenario may be associated with a high degradation of environmentally sensitive areas. Also, the unregulated spatial patterns of the predicted urban expansion under the BAU scenario may feature a high degree of leapfrogging/haphazard urban development (informal settlements), particularly in peri-urban/satellite settlements (Enoguanbhor et al. 2019; Agyemang and Silva 2019; Abubakar 2014; Goodfellow 2013; Trefon 2009). Such informal settlements comprise the majority of urban growth in Sub-Saharan Africa (Lall et al. 2017; Zubair et al. 2015; Freire et al. 2014; Schug et al. 2018; Hauer et al. 2018) and are characterized by deteriorating housing as home to low-income earners in the Global South (Gottdiener et al. 2016). The settlement patterns can be associated with poor sanitary environments that can affect the health of urban dwellers. Such patterns of urban development may pose a great challenge in creating a functional urban environment for future generations. Additionally, the positive association of roads, higher institutions, etc. with urban expansion patterns indicates that under the BAU scenario such spatial determinants may not be put under the effective control and may contribute to future haphazard urban expansion patterns.

The RLUP scenario that could not simulate land cover to 2050 implies that the limited space for future urban development may cause a challenge towards improving a functional urban environment, considering the high rate of urban expansion in the Global South. The economic and socio-cultural implications of implementing the RLUP scenario effectively are the cost of total evacuation and resettlement of all 
a

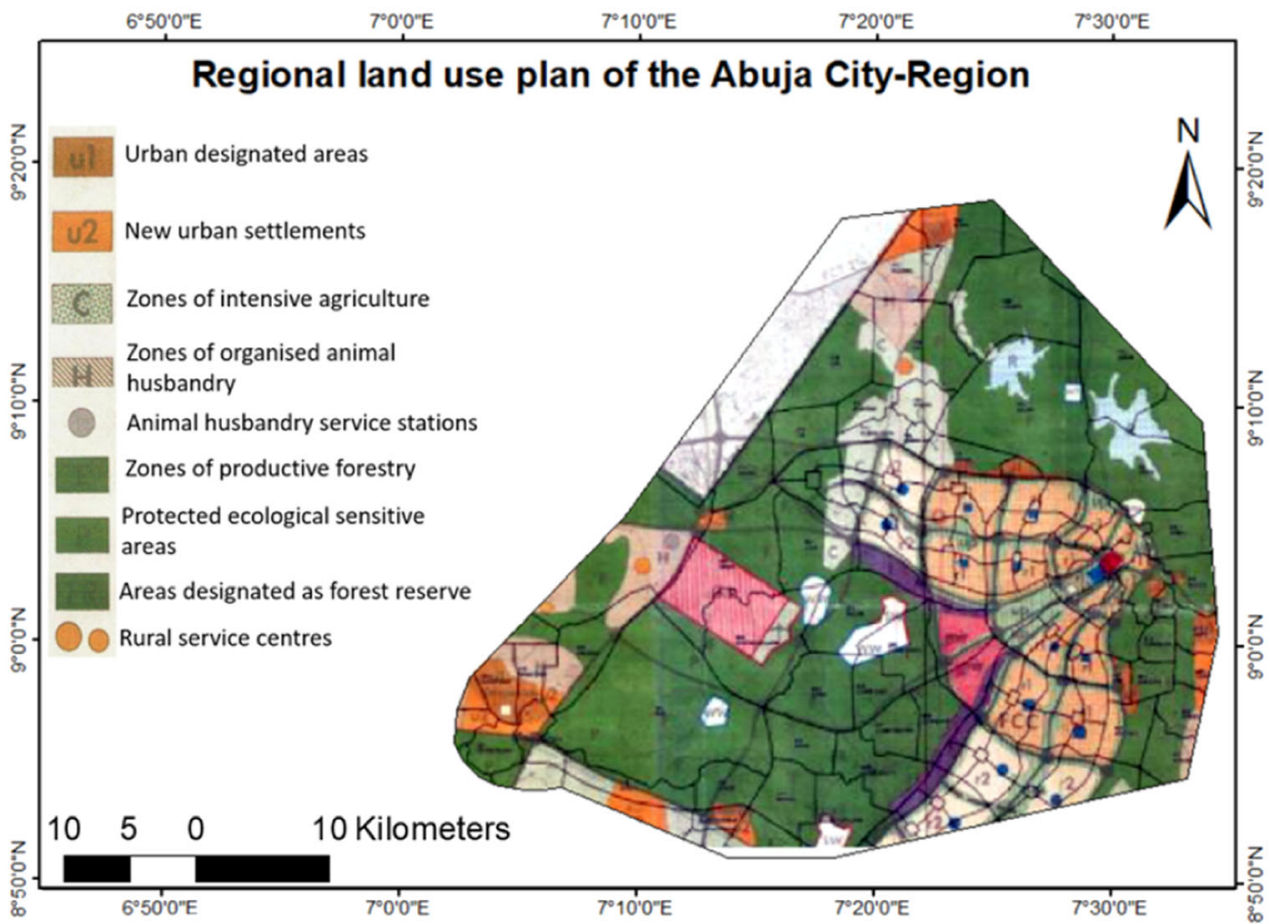

b Environmentally sensitive areas and urban/built-up ^ c Environmentally sensitive areas and urban/built-up under the BAU scenario

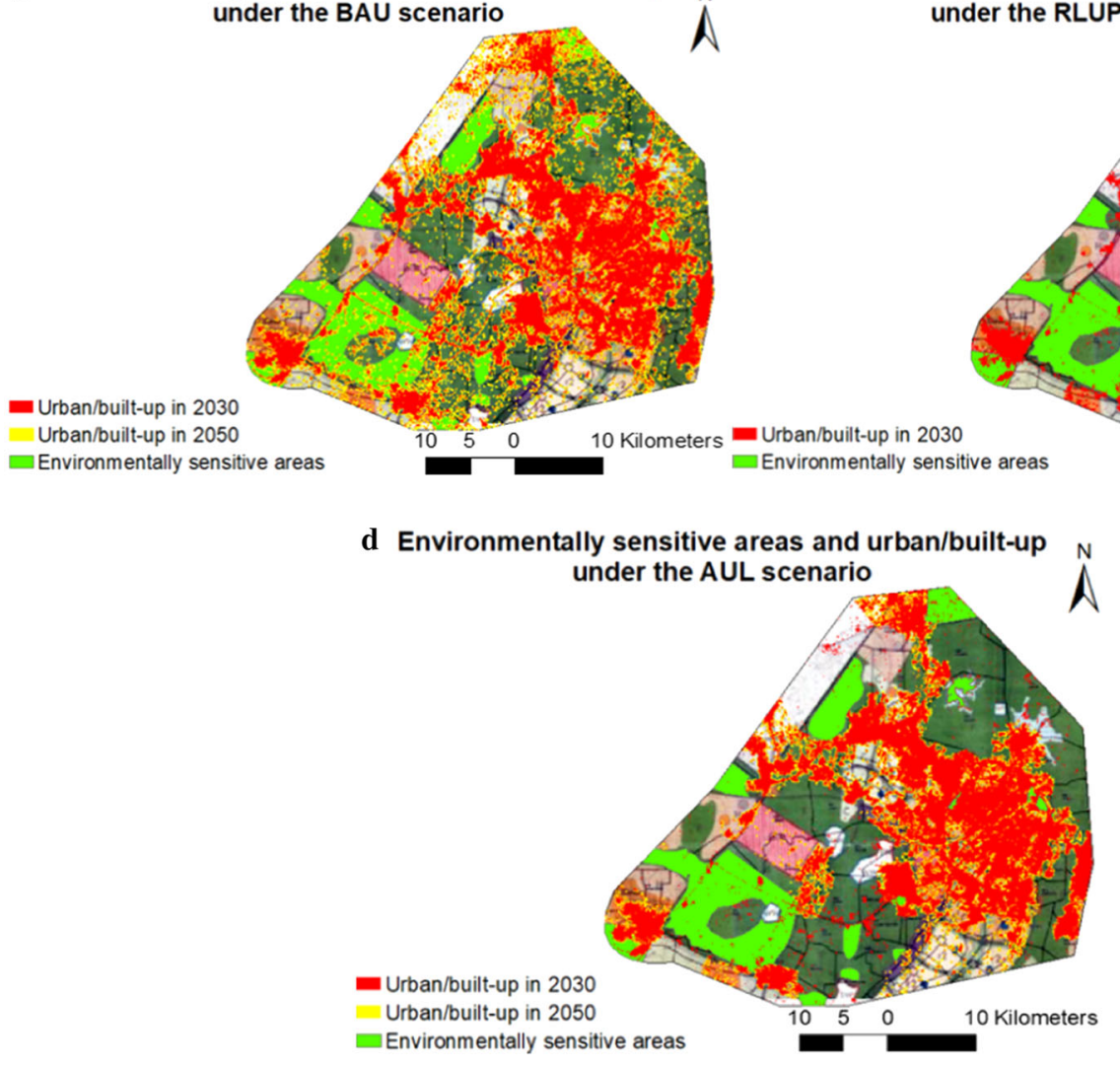


4 Fig. 5 Regional land use plan and the predicted urban/built-up land cover under the BAU, RLUP, and AUL scenarios

Table 8 The potential degradation of environmentally sensitive areas by possible future urban expansion

\begin{tabular}{lccl}
\hline & 2017 & 2030 & \multicolumn{1}{c}{2050} \\
\hline BAU scenario & $6.8 \%$ & $13.8 \%$ & $22.4 \%$ \\
RLUP scenario & $6.8 \%$ & $6.8 \%$ & - \\
AUL scenario & $6.8 \%$ & $8.3 \%$ & $9.0 \%$ \\
\hline
\end{tabular}

leapfrogged settlements and the demolition of the socio-cultural surroundings within the settlements.

However, the AUL scenario that simulated land cover to 2050 implies that the concept may allocate enough space to meet the need for urban expansion with little encroachment into land designated for nonurban development by the regional plan. Enough space would support the creation of a functional urban environment. Also, another positive implication of the AUL scenario is the protection of environmentally sensitive areas from urban expansion. This would help to improve the environmental objective of land use planning and contribute towards improving environmental sustainability. Additionally, the scenario has the potential to support the economic objective of land use planning, considering saving the cost of evacuating the major leapfrogged settlements and resettlements (e.g., Lugbe town). Furthermore, the scenario would help in preserving the socio-cultural heritage/surroundings within the leapfrogged settlements that are not under evacuation. Therefore, the AUL scenario can be said to have the potential for improving balancing the socio-cultural, economic, and environmental objectives of land use planning. The disadvantage of the AUL scenario, when compared to the RLUP scenario, is that some portion of land designated for non-urban development (e.g., agriculture, animal husbandry, forest reserves) by the regional plan may not be reclaimed for the initial purpose. The general implication of the spatial planning scenarios is the clarification of the contradicting opinions of the experts on the potential future demands for urban land expansion.

This study contributes to land use planning as a strategic instrument to regulate urban expansion and improve environmental sustainability by developing the AUL scenario of future urban expansion to quantify the associated environmentally sensitive areas that may be degraded. With the AUL scenario, this paper tends to improve the environmental objective of land use planning. The scenario could be used as an alternative measure to the BAU scenario of future urban expansion and to support the review of the current regional plan. Also, this study demonstrates how different scenarios can be used to reduce or eliminate uncertainties of the possible future urban expansion among experts. Furthermore, the study integrates GIS, RS, and survey-based data to investigate the spatial determinants of urban expansion that may be associated with its future leapfrogging/ haphazard spatial patterns under the BAU scenario. The methods and the baseline information provided in this study would be useful to inform decision-makers in urban and regional development planning/policies to improve the environmental sustainability of cityregions.

\section{Limitations}

One limitation of the present study is linked to the development of the AUL scenario without considering some important environmental components e.g., land for intensive agriculture, animal husbandry. However, we developed the scenario by considering the environmentally sensitive areas designated by the regional plan. Also, this study could have been limited by the pixel classification error of the RS data that could affect the model's calibration, validation, and final simulation of land cover. Additionally, the limitation of the study can be linked to the intentional/unintentional response bias during the survey of experts that could not be detected in the analysis.

\section{Recommendations}

As a result of the findings, this study recommends the following:

First, this study strongly recommends a comprehensive review of the regional plan. The results indicate that if the urban expansion pattern continues at a similar speed, it cannot be accommodated in the current regional plan up to 2050 even if the plan is implemented effectively. 
Second, while reviewing the urban and regional plans, the AUL concept for land use planning can be a useful tool to balance the needs for urban expansion and the protection of environmentally sensitive areas of city-regions. This would enable the major leapfrogged settlements to be incorporated into the urban and regional plans. For example, Lugbe town should be defined on the regional plan and should be incorporated into the Abuja city plan as one of the phases of the plan. The AUL scenario would help to mitigate the potential environmental impacts of the possible future urban expansion in environmentally sensitive areas under the BAU scenario to support the environmental objective of land use planning.

Third, the integrated empirical data derived from GIS, RS, and survey-based methods should be used to develop spatial planning (e.g., AUL, RLUP) scenarios to offer insights into the possible future urban expansion. This would reduce or avert the problem of insufficient data availability associated with land use planning when addressing urban expansion and environmental sustainability issues. Also, it would reduce uncertainties towards implementing regional plans of city-regions.

\section{Conclusions}

This study integrated empirical data derived from GIS, RS, and surveys of experts to offer insights into the possible future urban expansion under spatial planning scenarios to support land use planning and environmental sustainability of city-regions.

The investigation on spatial determinants of urban expansion indicated distances to roads, CBDs, higher institutions, shopping centers, urban planned areas, water bodies, and degrees of the slope as positively associated with urban expansion patterns. Conversely, the level of elevation and distance to protected areas are negatively associated with urban expansion patterns. Using expert interviews to guide the development of scenarios to simulate urban expansion, the BAU and AUL scenarios simulated land cover from 2017 to 2050 and the RLUP scenario simulated until 2030. Perhaps most alarming is the contradicting opinions from experts on the potential future demands for urban land expansion under different scenario implementation. The RLUP scenario provides evidence in support of the group of experts' opinions that land designated for urban development may not be sufficient for future urban expansion under the current regional plan. The AUL scenario, as a spatial planning alternative provides evidence in support of the group of experts' opinions on settlements that emerged through leapfrogging should not be evacuated but integrated into the master plan. Under the BAU scenario, this study indicated a high degradation of environmentally sensitive areas by the possible future urban expansion that may occur. Under the RLUP and AUL scenarios, the study showed that there may be no and little degradation respectively in the same areas.

This study shows that integrating empirical data derived from GIS, RS, and surveys is a useful approach to offer insights into the possible future urban expansion patterns to support land use planning. The approach and the baseline information derived, especially from the AUL scenario shows the possibility of balancing the need for urban expansion and the protection of environmentally sensitive areas in cityregions. This would be useful to improve balancing the socio-cultural, economic, and environmental objectives of land use planning for the purpose of improving the environmental sustainability of city-regions in Sub-Saharan Africa and across the Global South, where insufficient data availability challenges land use planning.

Acknowledgments The authors acknowledge Paul+Maria Kremer Stiftung for the PhD scholarship awarded to the first author. The authors are grateful to the USGS for making the remotely sensed data openly available and accessible. Also, the authors are grateful to AGIS (Abuja Geographic Information Systems), Abuja for making the land use plan available for the study.

Author Contributions All authors contributed significantly to this study. Particularly, Evidence Chinedu Enoguanbhor carried out the design, analysis, and interpretation of the work. Florian Gollnow, Blake Byron Walker, Jonas Ostergaard Nielsen, and Tobia Lakes reviewed the work critically and contributed to improving the manuscript. All authors read and approved the final manuscript.

Funding Open Access funding enabled and organized by Projekt DEAL.

\section{Compliance with Ethical Standards}

Conflicts of Interest The authors declare no conflicts of interest. 
Availability of Data and Material Not applicable.

Code Availability Not applicable.

Open Access This article is licensed under a Creative Commons Attribution 4.0 International License, which permits use, sharing, adaptation, distribution and reproduction in any medium or format, as long as you give appropriate credit to the original author(s) and the source, provide a link to the Creative Commons licence, and indicate if changes were made. The images or other third party material in this article are included in the article's Creative Commons licence, unless indicated otherwise in a credit line to the material. If material is not included in the article's Creative Commons licence and your intended use is not permitted by statutory regulation or exceeds the permitted use, you will need to obtain permission directly from the copyright holder. To view a copy of this licence, visit http://creativecommons.org/licenses/by/4.0/.

\section{References}

Abubakar, I. R. (2014). Abuja city profile. Cities, 41, 81-91. https://doi.org/10.1016/j.cities.2014.05.008

Adama, O. (2020). Abuja is not for the poor: street vending and the politics of public space. Geoforum, 109, 14-2315. https://doi.org/10.1016/j.geoforum.2019.12.012

Ade, M. A., \& Afolabi, Y. D. (2013). Monitoring urban sprawl in the Federal Capital Territory of Nigeria using Remote Sensing and GIS techniques. Ethiopian Journal of Environmental Studies and Management, 6, 82-95. https://doi. org/10.4314/ejesm.v6i1.10

Agbor, C. F., Aigbokhan, O. J., Osudiala, C. S., \& Malizu, L. (2012). Land use land cover change prediction of Ibadan metropolis. Journal of Forestry Research and Management, 9, 1-13. https://www.jfrm.org.ng/journal2012.html.

AGIS. (2007). FCT regional plan 2000: proposed landuse. Abuja: AGIS - Abuja Geographic Information Systems.

Agyemang, F. S., \& Silva, E. (2019). Simulating the urban growth of a predominantly informal Ghanaian city-region with a cellular automata model: Implications for urban planning and policy. Applied Geography, 105, 15-24. https://doi.org/10.1016/j.apgeog.2019.02.011

Agyemang, F. S., Silva, E., \& Poku-Boansi, M. (2019). Understanding the urban spatial structure of Sub-Saharan African cities using the case of urban development patterns of a Ghanaian city-region. Habitat International, 85, 21-33. https://doi.org/10.1016/j.habitatint.2019.02.001

Akintunde, J. A., Adzandeh, E. A., \& Fabiyi, O. O. (2016). Spatio-temporal pattern of urban growth in Jos Metropolis, Nigeria. Remote Sensing Applications: Society and Environment, 4, 44-54. https://doi.org/10.1016/j.rsase.2016.04. 003

Aldana-Domínguez, J., Palomo, I., Gutiérrez-Angonese, J., Arnaiz-Schmitz, C., Montes, C., Narvaez, F., et al. (2019). Assessing the effects of past and future land cover changes in ecosystem services, disservices and biodiversity: A case study in Barranquilla Metropolitan Area (BMA), Colombia. Ecosystem Services, 37, 100915. https://doi.org/10. 1016/j.ecoser.2019.100915
Babbie, E. (2010). The Practice of Social Research. Belmont: Wadsworth.

Babbie, E. (2013). The Practice of Social Research. Madrid: Wadsworth, Cengage Learning.

Barrera, F., \& Henríquez, C. (2017). Vegetation cover change in growing urban agglomerations in Chile. Ecological Indicators, 81, 265-273. https://doi.org/10.1016/j.ecolind. 2017.05.067

Blaxter, L., Hughes, C., \& Tight, M. (2001). How to research. Maidenhead: Open University Press, McGraw-Hill Education.

Bloch, R., Makarem, N., Yunusa, M., Parachristodoulou, N., \& Crighton, M. (2015). Economic development in urban Nigeria: Urbanisation Research Nigeria (URN). London: ICF International. Creative Commons Attribution-NonCommercial-ShareAlike CC BY-NC-SA.

Bryman, A. (2016). Social research methods. New York: Oxford University Press.

Campbell, J. B., \& Wynne, R. H. (2011). Introduction to Remote Sensing. New York: The Guilford Press.

Chang, K., Chen, Y., Han, F., Karacsonyi, D., \& Qian, Q. (2016). Investigating urbanization and its spatial determinants in the central districts of Guangzhou, China. Habitat International, 51, 59-69. https://doi.org/10.1016/j. habitatint.2015.10.013

Chen, J., Gao, J., Yuan, F., \& Wei, Y. D. (2016). Spatial Determinants of Urban Land Expansion in Globalizing Nanjing, China. Sustainability, 8(9), 868. https://doi.org/ 10.3390/su8090868

Chen, Y., Irwin, E. G., Jayaprakash, C., \& Irwin, N. B. (2017). Market thinness, income sorting, and leapfrog development across the urban-rural gradient. Regional Science and Urban Economics, 66, 213-223. https://doi.org/10.1016/j. regsciurbeco.2017.07.001

Chima, C. I. (2012). Monitoring and modelling of urban land use in Abuja Nigeria, using geospatial information technologies. Coventry: Coventry University.

COHRE (The Centre on Housing Rights and Evictions), \& SERAC (Social and Economic Rights Action Centre), . (2008). The myth of Abuja Master Plan: forced evictions as urban planning in Abuja, Nigeria. Geneva: COHRE.

Davoudi, S. (2009). City-Region. In R. Kitchin (Ed.), International Encyclopedia of Human Geography, (pp. 125-135). Amsterdam: Elsevier Ltd. https://doi.org/10.1016/B978008044910-4.00830-0

Doan, P., \& Oduro, C. Y. (2012). Patterns of population growth in Peri-Urban Accra, Ghana. International Journal of Urban and Regional Research, 36(6), 1306-1325. https:// doi.org/10.1111/j.1468-2427.2011.01075.x

Ejaro, S., \& Abubakar, A. (2013). Impact of rapid urbanization on sustainable development of Nyanya, Federal Capital Territory, Abuja, Nigeria. Journal of Applied Science and Environmental Management, 17, 299-313. https://doi.org/ 10.4314/jasem.v17i2.13

Enoguanbhor, E. C., Gollnow, F., Nielsen, J. O., Lakes, T., \& Walker, B. B. (2019). Land cover change in the Abuja CityRegion, Nigeria: integrating GIS and remotely sensed data to support land use planning. Sustainability, 11(5), 1313. https://doi.org/10.3390/su11051313

Fanan, U., Dlama, K. I., \& Oluseyi, I. O. (2011). Urban expansion and vegetal cover loss in and around Nigeria's 
Federal Capital City. Journal of Ecology and the Natural Environment, 3(1), 1-10. https://academicjournals.org/ journal/JENE/article-abstract/CE94A3B5892. Accessed 5 April 2019.

FMITI (Federal Ministry of Industry, Trade and Investment). (2015). Resettlement and social audit: Abuja technology village project. Abuja: FMITI.

Freire, M. O., Lall, S., \& Leipzige, D. (2014). Africa's Urbanization: Challenges and Opportunities. Washington, DC: The Growth Dialogue.

Gao, C., Feng, Y., Tong, X., Jin, Y., Liu, S., Wu, P., et al. (2020). Modeling urban encroachment on ecological land using cellular automata and cross-entropy optimization rules. Science of the Total Environment, 744, 140996. https://doi. org/10.1016/j.scitotenv.2020.140996

Goodfellow, T. (2013). Planning and development regulation amid rapid urban growth: explaining divergent trajectories in Africa. Geoforum, 48, 83-93. https://doi.org/10.1016/j. geoforum.2013.04.007

Google Earth (2018). 2019 Maxar Technology.

Gottdiener, M., Budd, L., \& Lehtovuori, P. (2016). Key Concepts in Urban Studies. London: Saga Publications Ltd.

Harding, A., Marvin, S., \& Robson, B. (2006). A Framework for City-Regions. London: ODPM Publications.

Hauer, J., Nielsen, J. Ø., \& Niewohner, J. (2018). Landscapes of hoping-urban expansion and emerging futures in Ouagadougou, Burkina Faso. Anthropological Theory, 18(1), 59-80. https://doi.org/10.1177/1463499617747176

Idoko, M. A., \& Bisong, F. E. (2010). Application of geo-information for evaluation of land use change: a case study of Federal Capital Territory-Abuja. Environmental Research Journal, 4, 140-144. https://doi.org/10.3923/erj.2010.140. 144

Inouye, C. E. N., de Sousa Jr, W. C., de Freitas, D. M., \& Simoes, E. (2015). Modelling the spatial dynamics of urban growth and land use changes in the north coast of Sao Paulo, Brazil. Ocean \& Coastal Management, 108, 147-157. https://doi.org/10.1016/j.ocecoaman.2014.12. 016

Jarvis, A., Reuter, H. I., Nelson, A., \& Guevara, E. (2008). Holefilled seamless SRTM. International Centre for Tropical Agriculture (CIAT). https://srtm.csi.cgiar.org. Accessed 15 May 2018.

Jelili, M. O., Adedibu, A. A., \& Egunjobi, L. (2008). Regional development planning in Nigeria: the general and particular. Journal of Social Sciences, 16, 135-140. https://doi. org/10.1080/09718923.2008.11892610

Kleemann, J., Inkoom, J. N., Thiel, M., Shankar, S., Lautenbach, S., Fürstf, C., et al. (2017). Peri-urban land use pattern and its relation to land use planning in Ghana, West Africa. Landscape and Urban Planning, 165, 280-294. https://doi. org/10.1016/j.landurbplan.2017.02.004

Koomen, E., \& Stillwell, J. (2007). Modelling land-use change: theories and methods. In E. Koomen, J. Stillwell, A. Bakema, \& H. J. Scholten (Eds.), Modelling Land-Use Change: progress and application (pp. 1-21). Dordrecht: Springer.

Kukkonen, M. O., Muhammad, M. J., Käyhkö, N., \& Luoto, M. (2018). Urban expansion in Zanzibar City, Tanzania: analyzing quantity, spatial patterns and effects of alternative planning approaches. Land Use Policy, 71, 554-565. https://doi.org/10.1016/j.landusepol.2017.11. 007

Lall, S. V., Henderson, V. J., \& Venables, A. J. (2017). Africa's Cities: Opening Doors to the World. Washington, DC: International Bank for Reconstruction and Development / The World Bank.

Larkham, P. J. (2000). Institutions and urban form: the example of universities. Urban morphology, 4(2), 63-77. https:// www.urbanmorphology.org/online_public/2000_2.shtml Accessed 27 September 2019.

Li, G., Sun, S., \& Fang, C. (2018). The varying driving forces of urban expansion in China: insights from a spatial-temporal analysis. Landscape and Urban Planning, 174, 63-77. https://doi.org/10.1016/j.landurbplan.2018.03.004

Linard, C., Tatem, A. J., \& Gilbert, M. (2013). Modelling spatial patterns of urban growth in Africa. Applied Geography, 44, 23-32. https://doi.org/10.1016/j.apgeog.2013.07.009

Lu, D., Weng, Q., Moran, E., Li, G., \& Hetrick, S. (2011). Remote Sensing Image Classification. In Q. Weng (Ed.), Advances in Environmental Remote Sensing: Sensors, Algorithms, and Applications (pp. 219-240). Boca Raton: Tailor \& Francis Group.

Mahmoud, M. I., Duker, A., Conra, C., Thiel, M., Ahma, H. S., et al. (2016). Analysis of Settlement Expansion and Urban Growth Modelling Using Geoinformation for Assessing Potential Impacts of Urbanization on Climate in Abuja City, Nigeria. Remote Sensing, 8, 220. https://doi.org/10. 3390/rs8030220

Mashi, S. A., \& Shuaibu, H. S. (2018). People and sustainable land management: assessment of stakeholders' knowledge of the nature of landuse/cover change in Abuja, Nigeria. GeoJournal, 83, 545-562. https://doi.org/10.1007/s10708017-9782-y

Maxwell, J. A. (2013). Qualitative Research Design: An Interactive Approach. Los Angeles, London, Washington DC: SAGA Publications inc.

Meyfroidt, P. (2016). Approaches and terminology for causal analysis in land systems science. Journal of Land Use Science, 11(5), 501-522. https://doi.org/10.1080/ 1747423X.2015.1117530

Mohamed, A., \& Worku, H. (2020). Simulating urban land use and cover dynamics using cellular automata and Markov chain approach in Addis Ababa and the surrounding. $U r$ ban Climate, 31, 100545. https://doi.org/10.1016/j.uclim. 2019.100545

NASRDA (National Space and Research Development Agency). (2012). Nigeriasat-2 SPOTMaps. Abuja: NASRDA.

Nnaemeka-Okeke, R. (2016). Urban sprawl and sustainable city development in Nigeria. Journal of Ecological Engineering, 17(2), 1-11. https://doi.org/10.12911/22998993/ 62277

Nor, A. N. M., Corstannje, R., Harris, J. A., \& Brewer, T. (2017). Impact of rapid urban expansion on green space structure. Ecological Indicators, 81, 274-284. https://doi.org/10. 1016/j.ecolind.2017.05.031

Olofsson, P., Foody, G. M., Herold, M., Stehman, S. V., Woodcock, C. E., Wulder, M. A., et al. (2014). Good practices for estimating area and assessing accuracy of land 
change. Remote Sensing of Environment, 148, 42-57. https://doi.org/10.1016/j.rse.2014.02.015

Phillips, P. M., \& João, E. (2017). Land use planning and the ecosystem approach: an evaluation of case study planning frameworks against the Malawi Principles. Land Use Policy, 68, 460-480. https://doi.org/10.1016/j.landusepol. 2017.08.006

Potts, D. (2012). Challenging the myths of urban dynamics in Sub-Saharan Africa: the evidence from Nigeria. World Development, 40(7), 1382-1393. https://doi.org/10.1016/j. worlddev.2011.12.004

Salem, M., Tsurusaki, N., \& Divigalpitiya, P. (2019). Analyzing the driving factors causing urban expansion in the PeriUrban areas using logistic regression: a case study of the greater Cairo region. Infrastructures, 4, 4. https://doi.org/ 10.3390/infrastructures 4010004

Schug, F., Okujeni, A., Hauer, J., Hostert, P., Nielsen, J. O., van der Linden, S., et al. (2018). Mapping pattern of urban development in Ougadougou, Burkina Faso, using machine learning regression modeling with bi-seasonal Landsat time series. Remote Sensing of Environment, 210, 217-228. https://doi.org/10.1016/j.rse.2018.03.022

Secor, A. J. (2010). Social Surveys, Interviews, and Focus Groups. In B. Gomez \& J. P. Jones (Eds.), Research Methods in Geography: A Critical Introduction (pp. 194-205). West Sussex: Blackwell Publishing Ltd.

Seto, K. C., Reenberg, A., Boone, C. G., Fragkias, M., Haase, D., Langanke, T., et al. (2012). Urban land teleconnections and sustainability. PNAS, 109(20), 7687-7692. https://doi. org/10.1073/pnas.1117622109

Shi, L., Shao, G., Cui, S., Li, X., Lin, T., Yin, K., et al. (2009). Urban three-dimensional expansion and Its driving forces-a case study of Shanghai, China. China. Chinese Geographical Science, 19(4), 291-298. https://doi.org/10. 1007/s11769-009-0291-x

Simwanda, M., \& Murayama, Y. (2018). Spatiotemporal patterns of urban land use change in the rapidly growing city of Lusaka, Zambia: implications for sustainable urban development. Sustainable Cities and Society, 39, 262-274. https://doi.org/10.1016/j.scs.2018.01.039

Singha, A., Imtiyaz, M., Isaac, R. K., \& Denis, D. M. (2012). Comparison of soil and water assessment tool (SWAT) and multilayer perceptron (MLP) artificial neural network for predicting sediment yield in the Nagwa agricultural watershed in Jharkhand, India. Agricultural Water Management, 104, 113-120. https://doi.org/10.1016/j.agwat. 2011.12.005

Sufiyan, I., Buhari, A. M., Abubakar, U. S., \& Ubangari, A. Y. (2015). An Overview of the Functions of Abuja Geographic Information System (AGIS) As a Tool for Monitoring Growth and Development in Abuja Nigeria. Journal of Environmental Science, Toxicology and Food Technology, 9 (11), 17-24. https://www.scribd.com/document/ 290931579/

Tope-Ajayi, O. O., Adedeji, O. H., Adeofun, C. O., \& Awokola, S. O. (2016). Land use change assessment, prediction using remote sensing, and GIS aided Markov Chain modelling at Eleyele Wetland Area, Nigeria. Journal of Settlements and Spatial Planning, 7(1), 51-63. https://doi.org/10.19188/ 06JSSP012016
Trefon, T. (2009). Hings and fringes: conceptualising the periurban in Central Africa. In F. Locatelli \& P. Nugent (Eds.), African Cities: completing claims on urban spaces (pp. 15-35). Leiden: Koninklijke Brill NV.

Tso, B., \& Mather, P. M. (2009). Classification methods for remotely sensed data. Boca Raton: CRC Press.

Tsutsumida, N., Saizen, I., Matsuoka, M., \& Ishii, R. (2015). Addressing urban expansion using feature-oriented spatial data in a peripheral area of Ulaanbaatar, Mongolia. Habitat International, 47, 196-204. https://doi.org/10.1016/j. habitatint.2015.01.024

Ujoh, F., kwabe, I. D., \& Ifatimehin, O. O. (2010). Understanding urban sprawl in the Federal Capital City, Abuja: Towards sustainable urbanization in Nigeria. Journal of Geography and Regional Planning, 3(5), 106-113. https:// academicjournals.org/journal/JGRP/article-abstract/ 5DEAA5539644. Accessed 28 August 2020

United Nations. (2019). Sustainable Development Goals Report. New York: United Nations Publications.

USGS (United States Geological Survey) (2019). USGS science for a changing world. https://earthexplorer.usgs.gov/. Accessed 02 April 2019.

Usman, L. S., (2013). The Dynamic of land Cover Change in Abuja City, Federal Capital Territory, Nigeria. Confluence Journal of Environmental Studies, 8 (1597-5827), 14-24. https://works.bepress.com/cjes_kogistateuniversity/29/. Accessed 25 August 2020

Visser, S., \& Jones, J. P., III. (2010). Descriptive Statistics. In B. Gomez \& J. P. Jones (Eds.), Research Methods in Geography: A Critical Introduction (pp. 279-296). West Sussex: Blackwell Publishing Ltd.

Wang, L. G., Han, H., \& Lai, S. K. (2014). Do plans contain urban sprawl? A comparison of Beijing and Taipei. Habitat International, 42, 121-130. https://doi.org/10.1016/j. habitatint.2013.11.001

Xie, W., Huang, Q., He, C., \& Zhao, X. (2018). Projecting the impacts of urban expansion on simultaneous losses of ecosystem services: a case study in Beijing, China. Ecological Indicators, 84, 183-193. https://doi.org/10.1016/j. ecolind.2017.08.055

Xu, Q., Zheng, X., \& Zhang, C. (2018). Quantitative analysis of the determinants influencing urban expansion: a case study in Beijing, China. Sustainability, 10 (5), 1-16. https://doi. org/10.3390/su10051630

Zhang, Q., \& Su, S. (2016). Determinants of urban expansion and their relative importance: a comparative analysis of 30 major metropolitans in China. Habitat International, 58 (C), 89-107. https://doi.org/10.1016/j.habitatint.2016.10. 003

Zubair, O. A., Ojigi, L. M., \& Mbih, R. A. (2015). Urbanization: a catalyst for the emergence of squatter settlements and Squalor in the vicinities of the Federal Capital City of Nigeria. Journal of Sustainable Development, 8(2), 134-148. https://doi.org/10.5539/jsd.v8n2p134

Publisher's Note Springer Nature remains neutral with regard to jurisdictional claims in published maps and institutional affiliations. 